IJTC

Ilomata International Journal of Tax \& Accounting

P-ISSN: 2714-9838; E-ISSN: 2714-9846

Vol. 1 No. 1 October 2019 page:35-40

https://www.ilomata.org/index.php/ijtc

\title{
The Influence of Account Receivable for Inventory of Income before Tax
}

\author{
Meilani $^{1}$, Pandoyo ${ }^{2}$ \\ ${ }^{12}$ STIE Bussiness Development and Management, Jakarta \\ Correspondence: meilani@higienis.com
}

Submitted: 6 August 2019.

20 Sept $2019 . \quad$ Published: 30 October 2019.

Revised: 23 August,

\begin{abstract}
This research aims to understand the influence of account receivable's variable simultantly or partially and Inventory of Income before tax from Multi Sarana Persada Inc. in research period 2012-2015. The test was using Multiple Regression Analysis. The result shows that account receivable's variable simultantly and inventory have an effect on income before tax. Account receivable's variable has a significant effect on income before tax. However, the inventory's variable does not affect income before tax.

Keywords: Multi Sarana Persada, Account Receivable, Inventory, Income before tax.
\end{abstract}

\section{INTRODUCTION}

Economic development which is faster in this era pushes business company in Coal Contractor Company, to increase their performance to keep surviving and growing. A good or bad condition of worker's performance can be detected from the achievement of management in increasing their performance, in that case, it is required an internal audit or internal control. Internal control in business company is handed by internal audit. Internal Auditor helps the company reaching a good performance, by introducing a systematic approach to evaluate and increase the effectivity of internal control and also give a note for the lack which is found when the evaluation was going around. To make an internal audit which can reach a big goal from their program and operational company activity is required a competent and indpendent auditor. The preview auditor part is just becoming a supervisor in the company who find their fault. However, on progress, nowadays internal audit can suggest internal audit data correction to improve the company's performance (Margaretha \& Hapsari, 2018).

The implementation of periodical Internal audit in a company is the right decision because one of the functions of internal audit is 
The Influence of Account Receivable for Inventory of Income before Tax Meilani, Pandoyo

improvement systematically and internal control evaluation in the company, test and assess the sufficiency effectivity of internal control system continuously. The Internal audit aimed to set systematically and evaluate internal control in the company. However, in practical it still does not run perfectly from the concept, because there is still defections and lack of responsiveness in the company.

Those defections usually occur in leadership pattern and employee's performance, because inconsistency between leadership pattern and employee's performance with the operative procedure or multiple tasks make internal control become not efficient. Internal control, leadership pattern and employee's performance are important because those are the cores in the company to reach the company's goal which is already arranged from the beginning. Internal audit activity tests and assesses the effectivity and sufficiency of the internal control system in the company, without the function of internal audit, director or the leader of the company has no sources for free internal information about employee's performance and company's performance too (Bintari, 2017).

Good performance is optimum performance, it is a performance which is appropriate with organization standard and giving support to reach the goal or vision of the organization. Good organization is an organization which gives the effort to improve human resource's quality because that is the key factor to improve employee's performance. Improving employee's performance will bring advance for the company to survive in business competition circles which is not really stable at all. Therefore, the effort to improve employee's performance is the most serious challenge of management because success to reach the goal and life of the company depends on the employee's performance inside. The company always hopes for the high quality of employee's performance. More employees have good performance, the production of the company will increase, thus the company can survive in global competition. Employees are demanded to able finishing tasks and their responsibility effectively and efficiently. The success of employee can be measured by satisfaction from the consumer, lack of complaint and reaching the company's target optimally.

Lanna Harita Inc employee's performance can be measured by completion of their order effectively and efficiently and also doing their part and their function well and all of those are connected each other and having positive relation for the success of a company. There are negative factors which can decrease employee's performance, they are decreasing employee's pretension to reach work achievement, lack of discipline of time in finishing their work, getting influence from their circle, friend worker who has a low spirit in work and there is no figure 
The Influence of Account Receivable for Inventory of Income before Tax Meilani, Pandoyo

who is precedent in reaching achievement of work. All of those are caused by decreasing employee's performance in work. Factors which can be applied to increase employee's performance are leadership style and motivation.

Most of Lanna Harita Inc employee feel that their salary which they got every month is not appropriate with the exist stipulation, they work on their portion even more but their salary which they receive is lack and not appropriate with their work, there are employee who already there since a long time ago got the salary less than new employee's salary. They do not even get paid for their overtime work, work outside of normal working hours make the employee always feel perforce to survive in this company. One of the employees who feel unpleasant and still holds out in this company decided to stay because that is very difficult to find another job. The employee also complains about their activity every day, when the bored is coming it will disturb their performance and the result from their work become not optimum. Therefore, this company strive for a refreshing activity for their employee once a year outside the office to make the office situation better.

\section{METHOD}

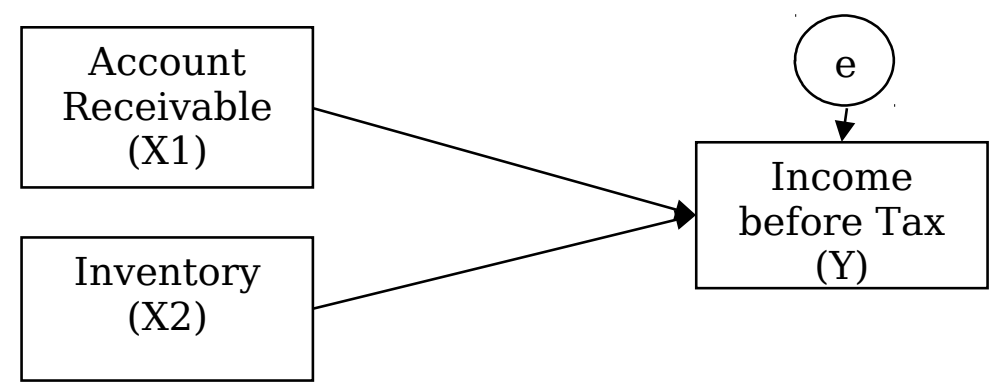

Picture 1. Research paradigm

Multiple Linear Regression equality is like this :(Ghozali, 2016):

$$
\mathbf{Y}=\boldsymbol{\alpha}+\boldsymbol{\beta}_{1} \mathbf{X}_{1}+\boldsymbol{\beta}_{2} \mathbf{X}_{2}+\varepsilon
$$

This research aims to understand how big the influence of internal audit and leadership simultantly and partially for employee's performance.

Table 1. The Definition of Operational Variable

\begin{tabular}{|c|c|c|c|c|}
\hline $\begin{array}{l}\mathrm{N} \\
\mathrm{O}\end{array}$ & Name of Variable & Concept & Indicator & $\begin{array}{c}\text { Measurin } \\
\text { g Scale }\end{array}$ \\
\hline 1 & $\begin{array}{l}\text { Account } \\
\text { Receivable }\left(\mathrm{X}_{1}\right) \\
\text { (Reeve, Warren, \& } \\
\text { Duchac, 2014) }\end{array}$ & $\begin{array}{l}\text { Account receivable is } \\
\text { claimed for selling by } \\
\text { a credit to the other } \\
\text { party }\end{array}$ & $\begin{array}{l}\text { Account } \\
\text { receivable = } \\
\text { Ln (Total of } \\
\text { account } \\
\text { receivable) }\end{array}$ & Ratio \\
\hline 2 & $\begin{array}{l}\text { Inventory }\left(\mathrm{X}_{2}\right) \\
\text { (Stice, Stice, \& } \\
\text { Skousen, 2009) }\end{array}$ & $\begin{array}{l}\text { Inventory is used for } \\
\text { available things to sell } \\
\text { in a normal business, }\end{array}$ & $\begin{array}{l}\text { Inventory = } \\
\text { Ln (Total of } \\
\text { Inventory) }\end{array}$ & Ratio \\
\hline
\end{tabular}


The Influence of Account Receivable for Inventory of Income before Tax Meilani, Pandoyo

\begin{tabular}{llll}
\multicolumn{5}{c}{$\begin{array}{l}\text { and in manufacture } \\
\text { company's case, this } \\
\text { word is used for the } \\
\text { process production or } \\
\text { placed in production } \\
\text { activity. }\end{array}$} \\
\hline $3 \quad$ Income before Tax & $\begin{array}{l}\text { Income before tax is } \\
\text { income from }\end{array}$ & $\begin{array}{l}\text { Income } \\
\text { (Y) }\end{array}$ \\
$\begin{array}{lll}\text { (Subramanyam, } \\
\text { operational on going } \\
\text { before sparing for }\end{array}$ & $\begin{array}{l}\text { Ln (Total } \\
\text { Income } \\
\text { earning tax }\end{array}$ & before Tax) \\
& & \\
& &
\end{tabular}

\section{RESULT AND DISCUSSION}

\section{The Influence of Account Receivable and Inventory Income Before Tax}

Account Receivable management in a company relates to receivable's rotation management and account receivable's submission period. Account receivable's rotation is a several time account receivable belongs to the company which turn over every year. Account receivable's rotation has a close relationship with account receivable's submission period. (Sundvik, 2016). The faster account receivable rotate, the efficiency of financial capital which is buried in account receivable will higher, and the higher of account receivable's rotation, the time that needed for account receivable's submission will shorter. (Fathoni, 2018). It means that if the rotation of account receivable run faster, the time that needed to make account receivable become cash is also faster. Hence, that cash can be used again for the company operation. Company for the policy which affect the number of account receivable finally affect to the company profitability too. (Wild, Subramanyam, \& Halsey, 2005). This shows that the company with all of their policy about account receivable will increase the earned and income because the risk of bad debt can be handed, thus the company profitability will increase too.

Table 2. F-Test output

\begin{tabular}{|c|c|c|c|c|c|}
\hline \multicolumn{6}{|c|}{ ANOVA $^{a}$} \\
\hline Model & $\begin{array}{c}\text { Sum of } \\
\text { Squares }\end{array}$ & Df & $\begin{array}{c}\text { Mean } \\
\text { Square }\end{array}$ & $\mathrm{F}$ & Sig. \\
\hline $\begin{array}{l}1 \text { Regress } \\
\text { ion }\end{array}$ & 0,750 & 2 & 0,375 & $\begin{array}{r}17,13 \\
9\end{array}$ & $\begin{array}{r}0,006 \\
b\end{array}$ \\
\hline Residua & 0,109 & 5 & 0,022 & & \\
\hline Total & 0,859 & 7 & & & \\
\hline
\end{tabular}

a. Dependent Variable: Income before Task

b. Predictors: (Constant), Inventory, Account Receivable

Table 3. Determination Coefficient Test Output

Model Summary ${ }^{b}$

38 | Ilomata International Journal of Tax \& Accounting

Vol. 1 No. 1 Oct 2019 
The Influence of Account Receivable for Inventory of Income before Tax Meilani, Pandoyo

\begin{tabular}{l|c|c|c|c}
\hline $\begin{array}{l}\text { Mode } \\
1\end{array}$ & $\mathrm{R}$ & $\begin{array}{c}\mathrm{R} \\
\text { Squar } \\
\mathrm{e}\end{array}$ & $\begin{array}{c}\text { Adjusted } \\
\text { R Square }\end{array}$ & $\begin{array}{c}\text { Std. Error } \\
\text { of the } \\
\text { Estimate }\end{array}$ \\
\hline 1 & $\begin{array}{r}0,934 \\
\mathrm{a}\end{array}$ & 0,873 & 0,822 & 0,14789 \\
\hline
\end{tabular}

a. Predictors: (Constant), Inventory, Account

Receivable

b. Dependent Variable: Income before Task

The first hypothesis declares that there is side-effect collectively between account receivable and inventory on income before tax. The result of research give a significant number of them, it is 0,006 that means with conviction level 95 percentage model is real, this explains that the first hypothesis is proven. The second effect is the free variable on income before tax, it is 82,2 percentage. The remaining 17,8 percentage is affected by the other variable outside research objects such as working capital and interest bank.

Table 4. Test-t Output

\begin{tabular}{|c|c|c|c|c|c|c|}
\hline \multicolumn{7}{|c|}{ Coefficients $^{\mathbf{a}}$} \\
\hline \multirow{2}{*}{\multicolumn{2}{|c|}{ Model }} & \multicolumn{2}{|c|}{$\begin{array}{l}\text { Unstandardized } \\
\text { Coefficients }\end{array}$} & \multirow{2}{*}{$\begin{array}{c}\text { Standardi } \\
\text { zed } \\
\text { Coefficien } \\
\text { ts } \\
\text { Beta }\end{array}$} & \multirow[t]{2}{*}{$\mathrm{t}$} & \multirow[t]{2}{*}{ Sig. } \\
\hline & & B & $\begin{array}{l}\text { Std. } \\
\text { Error }\end{array}$ & & & \\
\hline & (Constant) & $-60,379$ & 42,328 & & $1,426^{-}$ & $\begin{array}{r}0,21 \\
3\end{array}$ \\
\hline & $\begin{array}{l}\text { Piutang } \\
\text { Dagang }\end{array}$ & 3,687 & 0,851 & 0,943 & 4,331 & $\begin{array}{r}0,00 \\
7\end{array}$ \\
\hline & Persediaan &,- 122 & 2,105 &,- 013 &,- 058 & $\begin{array}{r}0,95 \\
6\end{array}$ \\
\hline
\end{tabular}

a. Dependent Variable: Income before task

\section{The Influence of Account Receivable on Income before Task}

One of the step to keep the customer which is already staying and draw new costumers is doing sell on the account. Selling on account will make account receivable. Account receivable generally is a claim which occurs because of selling thing or service on the account. Account receivable is maturity value which comes from selling thing or service or giving money loans (Wild et al., 2005). An Account receivable term includes all claim in money form to the other party, included individual, company, or the other organization (Reeve et al., 2014). Therefore, generally, account receivable occurs as a consequence of giving money loans to the other individual, company, organization or the other transaction which creates a relation between the party who give loans 
The Influence of Account Receivable for Inventory of Income before Tax Meilani, Pandoyo

and a party who is payable. Account receivable is on record in the balance sheet by debiting account receivable and classifying as circulating assets.

The second hypothesis declares that there is influence between account receivable with income before tax. The task result shows a significant number, 0,007 that means with conviction level 95 percentage model is real, this means that the second hypothesis is proven. Rate of influence from account receivable's variable on income before tax is 3,687 unit.

If the company determines the tight term of payment, it means that the company give first place to safety credits instead of profitability consideration (Riyanto, 2008). The examples of tight term of payment are they give a shorter time to payment deadline and a heavy interests in the late payment of receivables". The significant circle on receivables does not affect the dependent variable (ROI)(Suarnami, Suwendra, \& Cipta, 2014). The circle of receivable has no significant effect on increasing profitability in PT POS Indonesia (Bramasto, 2007).

\section{The Influence of Inventory to Income before Tax}

Inventory is one of the assets that is the most active in the operational activity of a merchandise company. Inventory also is the biggest and the most current asset from the manufacturing company or even merchandise company. The influence of inventory to income before tax is detected when business activity is fluctuating.

Inventory is one of the most important assets. It has a big part to the company, for example, make the operation of the company run currently which is finished consecutive start from the material, fabricating material goods and finished goods that in the next, they will be distributed to the consumers. For the companies, especially a concern in the retail and wholesale business, inventory is the biggest asset that belongs to the company compared with the other assets. Inventory is classified in a current asset because generally inventory can be changed to the case or the other assets in the operating cycle of the company.

The third hypotheses declared that there is influence from inventory to income before tax. The result of the test gives a significant score that is 0,956, it means the third hypothesis is proven (sig. 0,956 > $0,05)$. There is no significant effect from inventory to the profitability of the company (Surya, Ruliana, \& Soetama, 2017).

\section{CONCLUSION}

Simultantly, receivable's variable and inventory have an influence on income before tax that is 82,2 percentage. The other, 17,8 percentage is influenced by another variable outside the object of the research such as working capital and bank interests. 
The Influence of Account Receivable for Inventory of Income before Tax Meilani, Pandoyo

Partially, receivable's variable has a significant influence on the income before tax which is showed by a coefficient score of the regression that is 3,687. It means if account receivable's variable up one unit, income before tax will increase 3,687 units with the provision of inventory's variable is constant (ceteris paribus). Besides, inventory's variable has no influence to income before tax because the significant score is 0.956 ( $\operatorname{sig} .0,956>0,05$ ).

Based on the conclusion, the suggestion from this research is expected to the company that can increase account receivable, by high trade receivable will show the higher cash sales compared with the existing total. Account receivable also shows the skill of the company in operating receivable to the cash. The higher means the existence receivable become cash faster. By increasing cash in, it will increase the income of the company directly so that company income will increase too. The coefficient determination's result test shows that is still the other variable which must be considered in this research. Further research, it should add another variable that can affect income before tax.

\section{REFERENCE}

Bintari, W. C. (2017). Analisis Pengaruh Manajemen Modal Kerja Terhadap Kemampuan Pencapaian Laba Pada Usaha Dagang (Studi Kasus Pada Toko Di Sorong). Jurnal Noken: Ilmu-Ilmu Sosial, 2(1), 40. https://doi.org/10.33506/jn.v2i1.25

Bramasto, A. (2007). Analisis Perputaran Aktiva Tetap Dan Perputaran Piutang Kaitannya Terhadap Return On Assets Pada PT. POS Indonesia (PERSERO) Bandung. Jurnal Ekonomi UNIKOM, 9(2), 215230. Retrieved from https://jurnal.unikom.ac.id/jurnal/analisisperputaran-aktiva. $2 \mathrm{~h}$

Fathoni, A. (2018). Sistem Akuntansi Penerimaan Kas Pada KJKS BMT Mandiri Sejahtera Karangcangkring Gresik Jawa Timur. Al-Idarah: Jurnal Manajemen Dan Administrasi Islam, 2(1), 137. https://doi.org/10.22373/al-idarah.v2i1.3154

Ghozali, imam. (2016). Aplikasi Analisis Multivariete Dengan Program IBM SPSS 23 (Edisi 8). In Universitas Diponegoro. https://doi.org/https://doi.org/10.3929/ethz-b-000238666

Margaretha, F., \& Hapsari, A. D. (2018). Pengelolaan Modal Kerja Pada Usaha Kecil Dan Menengah di Indonesia. Jurnal Kesejahteraan Sosial, 2(02). https://doi.org/10.31326/jks.v2i02.159

Reeve, J. ., Warren, C. ., \& Duchac, J. . (2014). Principle of Accounting. In South Western.

Riyanto. (2008). Dasar Dasar Pembelajaran Perusahaan. In Dasar dasar 
The Influence of Account Receivable for Inventory of Income before Tax Meilani, Pandoyo

pembelajaran perusahaan. https://doi.org/10.1128/MCB.4.6.1134

Stice, Stice, J., \& Skousen, F. (2009). Akuntansi Keuangan Menegah. In Salemba Empat.

Suarnami, L. K., Suwendra, I. W., \& Cipta, W. (2014). Pengaruh Perputaran Piutang Dan Periode Pengumpulan Piutang Terhadap Profitabilitas Pada Perusahaan Pembiayaan. E-Journal Bisma Univesitas Pendidikan Ganesha, 2(1), 1-8. Retrieved from https://ejournal.undiksha.ac.id/index.php/JMI/article/viewFile/2092/1 825

Subramanyam, K. R. (2017). Analisis Laporan Keuangan. In Jakarta: Salemba Empat (11th ed.).

Sundvik, D. (2016). Earnings management around Swedish corporate income tax reforms. International Journal of Accounting, Auditing and Performance Evaluation, 12(3), 261. https://doi.org/10.1504/IJAAPE.2016.077892

Surya, S., Ruliana, R., \& Soetama, D. R. (2017). Pengaruh Perputaran Kas dan Perputaran Persediaan Terhadap Profitabilitas. Akuntabilitas, 10(2). https://doi.org/10.15408/akt.v10i2.6139

Wild, J., Subramanyam, K. R., \& Halsey, R. F. (2005). Analisis Laporan Keuangan. In Yanivi \& Nurwahyu (Eds.), Jakarta: Salemba Empat (8th ed.). Jakarta: Salemba Empat. 